historical sites. International Scientific and Practical Conference "World Heritage Sites: Sustainable Urban Heritage Practices", Kyiv, Ukraine. [in Ukrainian]

12. Exogenous geological processes. SRPE "Geoinform Ukrainy". http://geoinf.kiev.ua/ekzohenni-heolohichni-protsesy

13. Kahan, A. A., Kryvonohova, N.F. (2005). Methodology of geotechnical research in the reconstruction of buildings and structures. Geoekologiya, 3, 275-282.

14. Lomtadze, V.D. (1978). Engineering geology. Special engineering geology. Moscow: Nedra. [in Rassian].

https://doi.org/10.31713/m1124

\title{
ESTABLISHMENT OF REGULARITIES OF FLUVIOGLACIAL DEPOSITS AND PROBLEMS OF THEIR EXTRACTION IN THE DEVELOPMENT OF ROCK DEPOSITS OF BUILDING MATERIALS
}

Frolov A. A.

National Technical University of Ukraine "Igor Sikorsky Kyiv Polytechnic Institute", Doctor of Technical Sciences, Docent, Professor, Ukraine

\section{Zhukova N. I.}

National Technical University of Ukraine "Igor Sikorsky Kyiv Polytechnic Institute", Candidate of Technical Sciences, Docent, Ukraine

\section{Lytvynchuk I. D.}

National Technical University of Ukraine "Igor Sikorsky Kyiv Polytechnic Institute", PhD Student, Ukraine

\section{Beltek M. I.}

National Technical University of Ukraine "Igor Sikorsky Kyiv Polytechnic Institute", PhD Student, Ukraine

\section{Lukomskyi V. R.}

Taras Shevchenko National University of Kyiv, student, Ukraine

\section{Abstract}

The subject of research in the presented scientific work are the patterns of distribution and features of fluvioglacial deposits on the territory of Ukraine, as well as possible technological schemes and equipment complexes for extraction of fluvioglacial deposits. 
Methodology. To solve these problems was used a comprehensive approach, which consists of: analysis and generalization of previous research in the field of studying the peculiarities of occurrence of fluvioglacial deposits, as well as the effectiveness of using technological complexes for the extraction of gravel-sand mass; technological substantiation of the offered scientific decisions; analytical calculation of the productivity of the technological complex depending on the size of the rock mass.

The aim of the research is to substantiate the expediency and efficiency of using the proposed bulldozer-excavator-automobile complex with the use of ripperbulldozers to remove the overburden layer of fluvioglacial deposits in rock deposits.

Results of the research. Based on the current state of mining operations and the availability of the existing equipment in the quarries of Sosnivsky and Yaroshivsky deposits for the removal of the layer of fluvioglacial deposits, the use of a combined bulldozer-excavator-automobile complex is recommended. Depending on the size of the work area, there are two options. In the first case, it is proposed to use a hydraulic excavator with a backhoe, placed on the covering of overburden. In the second version of the excavator type «straight shovel» is located below the working horizon and is loaded with gravel-sand mass, which is dumped by a bulldozer.

Empirical and graphical dependence of the variable productivity of the excavator on the average size of a piece of gravel-sand mass for the quarry conditions of the Sosnivsky deposit is obtained. It is established that within the limits of change of size of gravel-soil materials from 20 to $120 \mathrm{~mm}$, productivity of excavators decreases 1,43 times: for the return shovel from $624,1 \mathrm{~m}^{3} / \mathrm{shift}$ to $436,2 \mathrm{~m}^{3} / \mathrm{shift}$; for straight shovel from $728,1 \mathrm{~m}^{3} / \mathrm{shift}$ to $508,8 \mathrm{~m}^{3} / \mathrm{shift}$. In general, the productivity of the excavator with a straight shovel is $17 \%$ higher than the productivity of the backhoe.

\section{Introduction}

In recent years, the mining of mineral raw materials (mainly building materials) in an open way reveals new patterns of structure of the sedimentary complex and even the upper part of the crystalline basement of the Middle Dnieper. In particular, this applies to fluvioglacial deposits, which are distributed in sufficient quantities in Ukraine.

The features of the extraction of fluvioglacial sediments, which affect the justification of the parameters and the choice of technological schemes of their development, include [1-3]:

- a wide range of changes in the properties of rocks that are part of these deposits, particle size distribution, the presence of layers of other rocks;

- a variety of conditions of mineral occurrence;

- the degree of water of fluvioglacial deposits;

- heterogeneity of quality indicators of deposits; 
- a significant change in the volume of their occurrence in some areas.

Timely detection of these features determines the further efficiency of the removal of fluvioglacial deposits. The reliability of geological information at the stage of geological surveys is important in this case. Taking into account changes in the geological conditions of deposits within the land allotment, namely changes in the fractional composition of gravel and sand mass, especially the content of coarse gravel and boulders, and the presence of interlayers allows at the design stage of the mining company to take measures to prevent complex emergencies in the workplace.

In the development of gravel and sand deposits, ie when fluvioglacial deposits are classified as minerals, geological assessment of occurrence conditions is performed for an individual object when preparing a feasibility study to calculate reserves. According to the instructions for the application of the classification of reserves, gravel and sand deposits are divided by size and quality characteristics of the productive layer, [1] namely:

- large and medium-sized stratum and stratum-type with variable quality properties of sand and gravel;

- small lenticular with unsustainable power and inconsistent quality of useful components.

As we can see, the volume of minerals within the field, the structure of the deposit, and the content of gravel and boulders are the most important indicators that determine the economic efficiency of field development.

When designing the development of rocks, the deposits of which are covered with gravel-sand mass, fluvioglacial deposits are referred to as overburden. In this case, little attention is paid to the structure of their occurrence and patterns of distribution of the fractional composition, which in the future, during the development of the field, may be difficult, and in some cases impossible, to remove the layer of overburden.

In recent years, in mining in the development of mineral deposits in the open method, scientists have identified several important areas for improving the extraction of minerals [4,5]. These include determining the conditions for safe and efficient operation of mining equipment, qualitative justification for establishing rational parame- 
ters of development systems, improvement of technological schemes of mining and processing of minerals and selection of the most expedient technological complexes of equipment.

If these areas are attributed to the removal of fluvioglacial deposits, the issue of safety and efficiency of their development is particularly acute, as they have received insufficient attention. Therefore, the development of recommendations that determine the effective operation of a particular technological complex in specific conditions of the field is an important scientific and technical task.

Thus, the analysis of scientific publications and industrial experience in the development of fluvioglacial deposits shows that the technological process of their extraction needs to be improved primarily through justification and selection of optimal for the given conditions, technological complex of equipment.

\section{Regularities of fluvioglacial deposits on the territory of Ukraine}

Fluvioglacial includes a group of sediments that are formed as a result of washing out, transfer and deposition of moraine material by streams of melting glacial waters. There are two main genetic types of fluvioglacial deposits: intraglacial and glacial (periglacial). Intraglacial deposits are formed as a result of deposition of material inside the melting glacier (in the upper and inside glacial ice channels). Glacial deposits have accumulated outside the melting glacier as a result of the deposition of meltwater material washed from intraglacial areas and marginal moraines.

Fluvioglacial deposits are genetically related to moraines, but in contrast they usually have a certain sort by size of material, can be layered and occur in the form of removal cones, lenses and channels of intraglacial flows. Glacial deposits are characterized by rapid change of coarse pebbles and boulder sands with fine-grained obliquely stratified sands as they move away from the glacier.

Fluvioglacial deposits in the form of cones of removal are the most common and occur cloak-shaped with erosion on the final and main moraines. Their thickness is quite unstable, ranging from 0.5$3.5 \mathrm{~m}$ above the moraine to $16-35 \mathrm{~m}$ on the beds and hills. The removal cones are mainly composed of packs of well-washed and sorted sand-gravel-pebble material from boulders, sand and gravel- 
pebble-boulder deposits (Fig. 1) [6]. These deposits are often overlayered in sections and contain inclusions of ablative moraine. The thickness of fluvioglacial rocks has a horizontal stratification with a small distal slope, and in the interlayers and lenses - oblique and horizontal stratification. The angle of inclination of the obliquely layered series is $7-45^{\circ}$. In the removal cones, subsidence dislocations are observed, which are expressed in discharges, flexor-like bends of stratification, and others. More coarse pebble-boulder and sand-gravel material usually lies on high inland areas. In the distal direction, the debris of the removal cones becomes smaller and more homogeneous. Fluvioglacial deposits often contain lenses, pellets and blocks of the main moraine, and on the slopes are covered with a cover of ablative moraine.

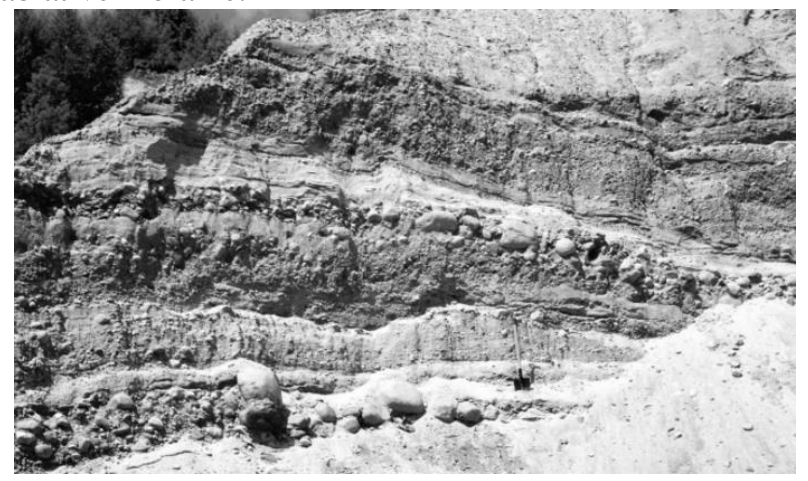

Fig.1. An example of the deposition of fluvioglacial cones of removal in the quarry [6]

Fluvioglacial deposits, according to the ICS (International Stratigraphic Commission), belong to the Quaternary system and are confined to the upper tier of the Pleistocene part of the Quaternary system (Table 1) [7].

Table 1

Subdivisions of the Quaternary sediment system

\begin{tabular}{c|l|l|l}
\hline \multirow{2}{*}{ System } & \multicolumn{1}{|c|}{ Series } & \multicolumn{1}{c|}{ Stage } & \multicolumn{1}{c}{ Age, m.y.a } \\
\hline \multirow{5}{*}{ Quaternary } & \multirow{3}{*}{ Holocene } & Meghalayan & $0,0042-0$ \\
\cline { 3 - 4 } & & Northgrippian & $0,0082-0,0042$ \\
\cline { 3 - 4 } & & Greenlandian & $0,0117-0,0082$ \\
\cline { 2 - 4 } & \multirow{4}{*}{ Pleistocene } & Upper & $0,129-0,0117$ \\
\cline { 3 - 4 } & & Chibanian & $0,774-0,129$ \\
\cline { 3 - 4 } & & Calabrian & $1,80-0,774$ \\
\cline { 3 - 4 } & & Gelasian & $2,58-1,80$ \\
\hline
\end{tabular}


Continental types of Quaternary deposits are widespread on the territory of Ukraine: aeolian-deluvial, glacial (actually glacial and waterglacial), alluvial (Figs. 2 and 3) [8,9]. They are the result of the Middle Pleistocene glaciation of the Oka River and the Dnieper River.

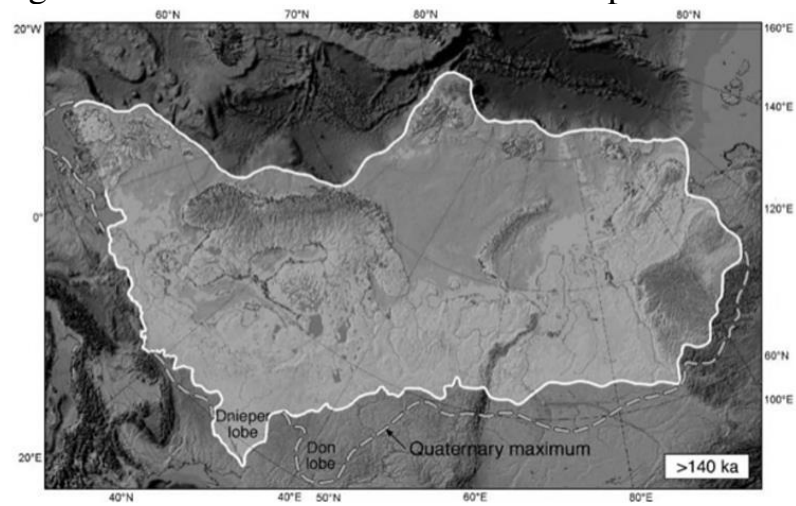

Fig. 2. Limits of distribution of cover glaciers [8]

Actually glacial deposits, or moraines, consisting of unsorted fragments of bedrock, boulder clays, loams, sands are common within the ancient (Oka and Dnieper) glaciation.

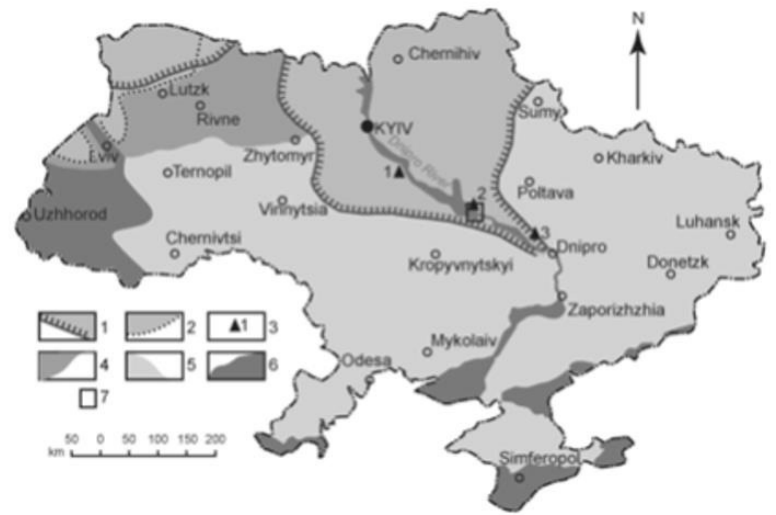

Fig. 3. Simplified map of Quaternary glacial deposits of Ukraine: 1 - the southern border of the Dnieper glaciation; 2 - the southern boundary of the Elster (Oka) glaciation; 3 - glaciodislocations (1 - Kaniv, 2 - Pyvykha, 3 - Kalytva); 4 - falling out zone of fluvioglacial deposits; 5 - territory of forest and forest-like deposits; 6 - areas where glacial deposits are not common; 7 - the area under study [9] 
The Oka Glacier was distributed only in the extreme northwestern part of Ukraine. This glacier is comparable to the Ulster Glacier of Western Europe.

The Dnieper Glacier is comparable to the Western European Saalia Glacier. The Dnieper moraine is spread over large areas of the Polissya lowland, Podil upland, Dnieper upland and Dnieper lowland. The most distinctive features of the Dnieper (Ryska) ice age in the north of the Middle Dnieper are the giant erratic boulder on the right bank of the Dnieper near the village Domotkan' and morainefluvioglacial hill, known as Mount Kalytva. The glacial tongue stretched far to the south and reaches the latitude where the city of Kamyanske is located [9].

The southern limit of the distribution of glacial deposits passes near the Dnipro. The thickness of rocks of glacial genesis varies from a few to $20-30 \mathrm{~m}$, sometimes up to $100 \mathrm{~m}$. Glaciodislocations and glaciodistrictors are widespread in the regional zone of the Dnieper Glacier. Water-glacial (fluvioglacial) deposits (sands, pebbles, sandy loams, loams, clays) lie above and below the moraine, and also form peculiar landforms (kames, eskers, sandr). Subaquatic clays, sandstones, sands, peat, gyttja with a total thickness of up to 5-10 m accumulated in the interglacial period, and subaquatic fossil soils accumulated outside the glaciation. In the periglation zone of the glacier (the so-called cold steppe) loess were formed.

In the northern regions of Ukraine there are both glacial and fluvioglacial deposits. Glacial deposits or tills composed of unsorted boulders and pebbles of different composition and age in a fine-grained clay silt matrix. Sediment thickness from 0,5 to more than $18 \mathrm{~m}$ [9].

Fluvioglacial deposits often underlay and even cover the till and create characteristic landforms - kames, eskers and sandy plains. Terrain forms are mainly composed of sandy, clayey rocks. The thickness of water-glacial formations varies from the first meters to $50 \mathrm{~m}$, the maximum - 100-120 $\mathrm{m}$.

Areas to the south and east of the tills are covered with loess deposits in which burial horizons of paleosoils are found. Total capacity from 5 to $50 \mathrm{~m}$.

Scientists have identified two mutual glacial sheets. The NorthWestern or Scandinavian-Finnish stream, dominated by boulders from Sweden and Western Finland, occupies a large part of Belarus 
and the territory west of the Volyn region of Ukraine. The second Nord Stream covered large areas of the European part of Russia, Belarus, as well as the northern and central parts of Ukraine. The Nord Stream was formed later than the Scandinavian-Finnish Stream and was much longer. Boulders and pebbles of northern and northeastern origin have in their composition mainly of Vyborg rapakivi, Shokshin sandstones, Silurian Devonian and coal sandstones [9].

The Dnieper climatolite is composed of glacial formations that lie on pre-Quaternary deposits and are widespread in the glacial zone. Dnieper climatolite is divided into lower, middle and upper Dnieper stadials. The Lower Dnieper stadial is composed of fluvioglacial deposits - fPIIdn1. The Middle Dnieper stadial is represented by lakeglacial, moraine and fluvioglacial deposits, which correspond to the middle and upper packs of the "Shevchenko suite" - $\lg$ PII $d n 2$. The section of the lower part of the Middle Dnieper climatolite is completed by lake-glacial deposits that cover the bottom moraine. The Upper Dnieper stadial is represented by the regional moraine $g k$ PII $d n 3$, the outputs of which are best represented on Mount Kalytva. Fluvioglacial deposits of Kalytva are very dislocated, oblique layered, diverse in granulometric composition, sometimes containing carbonized plant remains, fragments of petrified wood [8].

\section{Technological complexes of equipment for extraction of fluvi- oglacial deposits}

Of the total number of quarries of non-metallic building materials located within the Dnieper glaciers, a significant share (10-20\%) are quarries that develop sand-gravel deposits of fluvioglacial deposits, ie they are used as minerals for sand production, stone and rubble. However, in many cases, in particular in the extraction of building stone on rubble or blocks, fluvioglacial deposits are classified as overburden, because they are located on top of the rock mass and completely or partially block access to the mineral [10]. The average thickness of such deposits is about $10 \mathrm{~m}$. Traditional technologies for removing the layer of fluvioglacial deposits, which are used in their development as minerals, in deposits of rock building materials are usually inefficient and impractical, as the vast majority of them use hydromechanization equipment. Deposits of boulders of considerable size require powerful extraction and loading equipment. It should 
also be noted that the problem of removal of fluvioglacial deposits usually arises in quarries not at the stage of discovery of the deposit, but in the process of its development. In this case, the process of removing the layer of sand-gravel mixture is further complicated by the limited working space and the lack of appropriate extraction equipment.

The technology of development of fluvioglacial (sand-gravel) deposits depends on the percentage of gravel-boulder material in them. Gravel-boulder material can be placed on the entire thickness of the sediment, and form local areas of accumulation. Therefore, it is very important at the stage of field exploration to study in detail the composition and structure of the thickness of the overlying rocks composed of fluvioglacial deposits.

In [11] the following classification of fluvioglacial (sand-gravel) sediments (Table 1) is proposed.

Table 2

Fractional composition and size of fluvioglacial deposits

\begin{tabular}{l|l|c}
\hline \multicolumn{2}{c|}{ Fractions } & Size, mm \\
\hline \multirow{4}{*}{ Boulders } & Large & more 400 \\
\cline { 2 - 3 } & Medium & $201-400$ \\
\cline { 2 - 3 } & Small & $101-200$ \\
\hline \multirow{4}{*}{ Gravel } & Large & $41-100$ \\
\cline { 2 - 3 } & Medium & $21-40$ \\
\cline { 2 - 3 } & Small & $5-20$ \\
\hline \multirow{4}{*}{ Sand } & Coarse-grained & $1-5$ \\
\cline { 2 - 3 } & Medium-grained & $0,5-1,0$ \\
\cline { 2 - 3 } & Medium-fine-grained & $0,25-0,5$ \\
\cline { 2 - 3 } & Fine-grained & $0,1-0,25$ \\
\hline Dusty and silt particles & & $0,005-0,1$ \\
\hline Clay particles & & less 0,005 \\
\hline
\end{tabular}

The thickness of sediments in different areas can vary from a few meters to 25-40 $\mathrm{m}$ and more.

Also, according to scientists, when estimating fluvioglacial sediments, depending on the average content and ratio of sand, gravel and boulders, it is necessary to use certain geological terms (Table 3) [12]. 
Table 3

Names of gravel-sand rocks depending on the ratio of sand, gravel and boulders

\begin{tabular}{l|c|c|c}
\hline \multirow{2}{*}{ Rock } & \multicolumn{3}{c}{ Contents, \% } \\
\cline { 2 - 4 } & sand & Gravel and boulders & Boulders \\
\hline Sandy & $90-100$ & $\leq 10$ & 0 \\
\hline Gravel-sandy & $10-90$ & $10-90$ & $\leq 5$ \\
\hline Boulder-gravel-sandy & $10-90(85)^{*}$ & $10-90(85)^{*}$ & $>5(5-80)^{*}$ \\
\hline
\end{tabular}

Technological schemes for the development of sand and gravel deposits and the equipment used are very diverse. This is due to the difference between mining and geological and hydrogeological conditions, the volume and thickness of sediments, the service life of the quarry, the fractional composition of the material that makes up the thickness of the cover rocks, and the availability of equipment to effectively remove the fluvioglacial layer.

The most common equipment for the extraction of such rocks are excavators, namely excavators such as «mechanical shovel», hydraulic excavators with direct or reverse shovel and draglines. Rotary and multi-bucket excavators, wheel loaders, bulldozers, wheel scrapers, rope scrapers, tower excavators and hydromechanization equipment are much less commonly used. If the field is flooded, floating dredgers with different types of executive body are used.

At development of dry layers of fluvioglacial deposits the technological scheme with excavator extraction of breeds frontal pit face and loading in motor transport is recommended. The main advantages of this scheme are the operational separation of boulders and coarse-grained material from the main rock mass, selective extraction of layers of sand, clay and sand-gravel rocks (if fluvioglacial deposits are represented by them). However, if the volumes of fluvioglacial deposits are small and they are developed as the mining front advances in the quarry, the technological scheme of excavation of this layer of rocks with the help of excavators is very difficult to implement, and in some cases impossible. This is due to the limited space for mining, namely the small size of the work site, or the lack of powerful quarry excavator equipment capable of developing a compacted boulder-gravel stratum. 
If the deposit is partially flooded, draglines are mainly used, which stack gravel-sandy rock mass in piles for dewatering to natural humidity. After that, the rocks are shipped by different types of loading equipment to vehicles. There are several technological schemes for processing fluvioglacial deposits with draglines, depending on the degree of waterlogging of rocks, the thickness of the gravel-sand mass and its volume and the width of the mining front [11]. However, in deposits of rocks covered with fluvioglacial deposits, which are related to overburden, the use of dragline to extract sand-gravel stratum is possible only in powerful deposits with a significant volume of overburden, low content of boulder and gravel material and at the stage of discovery the front of mining operations (namely the width of the work site) is not limited by mining ledges.

Rope scrapers and tower excavators can be used effectively in the development of dry and waterlogged rocks. The capacity of the rope scraper bucket can be $4 \mathrm{~m}^{3}$ and more, and the distance between the towers can exceed $200 \mathrm{~m}$. The main tower of the rope scraper can be movable or immovable. There is experience in the use of rope scrapers in the development of sand and gravel deposits, ie when fluvioglacial deposits are classified as minerals. The main disadvantages of field development with rope scrapers and tower excavators include: leaving the pillars in places adjacent to the main support, losses in which can reach up to $20 \%$ [13]; sharp decrease in productivity of work of the equipment at increase in distance of scraping; inability to use in the winter. Also, the efficiency of the tower equipment is significantly affected by the particle size distribution of sand-gravel mass and the presence of boulders.

Therefore, it is obvious that the use of rope scrapers and tower excavators in rock deposits to remove the layer of fluvioglacial deposits will be inefficient and impractical due to the small volume of disclosure.

Scraper technological complexes are mainly used for mining and preparatory works, as well as as the main equipment in the development of placer and sand-gravel deposits. The extraction of sand and gravel rocks is carried out under the condition that the mountain massif is represented by soft rocks and in the absence of boulders. Movement of the scraper is possible on rise no more than 10 . The effective average transport distance is not more than $600 \mathrm{~m}$ with a 
bucket capacity of 6-10 $\mathrm{m}^{3}$ [14]. Scraping schemes are characterized primarily by the location of the dump relative to the contour of the quarry. For the removal of the layer of fluvioglacial deposits, the most acceptable schemes are the placement of rock mass on board the quarry (the simplest and most economical) (Fig. $4 a$ ) or on external dumps (less appropriate) (Fig. 4b).
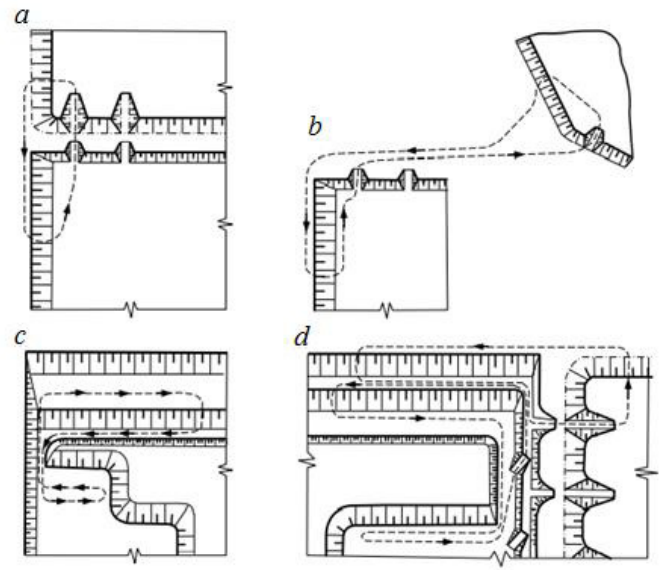

Fig. 4. Basic scraping schemes [14]

When using scraper technological complexes, the extraction of rocks is usually carried out by end faces. The minimum length of the face should not be less than the distance of filling the rock with a scraper bucket $1 \mathrm{H}$. For medium power and powerful scrapers, it is 30 $50 \mathrm{~m}$.

At preliminary preparation of breeds for extraction by mechanical loosening of inclined layers the minimum length of a face $l_{\text {B.min }}>50 \mathrm{~m}$. To reduce the downtime of the scraper complex in the presence of strong inclusions (boulders, etc.), waterlogging of rocks, etc. it is necessary that the length of the face satisfies the condition.

$$
l_{\mathrm{B}}>2 l_{\mathrm{B} \cdot \min },
$$

that is, the length of the scraper face during the development of soft and dense rocks was not less than 60-100 m.

Therefore, the possibility of using scraper complexes in the extraction of overburden rocks represented by fluvioglacial deposits is 
influenced by the presence (absence) of boulders and a sufficient length of the face to fill the scraper bucket.

Bulldozers are widely used in mining and preparatory, planning and ancillary works, as well as the main equipment in the development of placer and sand-gravel deposits. The development is carried out by fans, parallel longitudinal or transverse, diagonal or combined approaches (Fig. 5). The average distance of rock mass transportation by bulldozers varies between $70-120 \mathrm{~m}$. When calculating the productivity of the bulldozer complex, it is necessary to take into account the complexity of rock excavation, the distance of rock mass movement and the content of boulders.
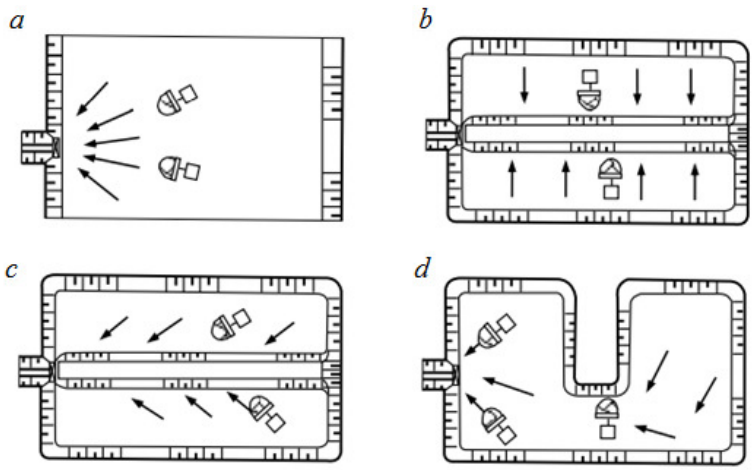

Fig. 5. Options for the development of placer and sand-gravel deposits [14]

Bulldozer development of overburden is considered appropriate if it is performed at the power of overburden $H_{p} \leq 3-4 \mathrm{~m}$ and moving a distance $L \leq 100-150 \mathrm{~m}$ in external dumps. With increasing power of bulldozers ( $200 \mathrm{~kW}$ and more), their use in the open pit in the development of fluvioglacial deposits is effective in $H_{p} \leq 6-10 \mathrm{~m}, L \leq 200$ $250 \mathrm{~m}$ and at an angle of rise up to $27^{\circ}$.

From the combined technological complexes which can be applied to extraction of fluvioglacial deposits, it is possible to allocate scraper-bulldozer and bulldozer-excavator complexes $[14,15]$. They are used to create the most efficient working conditions for each or the main type of equipment. First of all, the distance of movement of the rock mass by bulldozers decreases. Scraper-bulldozer technological complexes are usually used in mining operations in the develop- 
ment of placer deposits and deposits of construction rocks. In this case, the scrapers remove the rock by pits-platforms (transverse steps, Fig. 6a) or frontal pits (Fig. 6b). Bulldozers carry out dump formation.
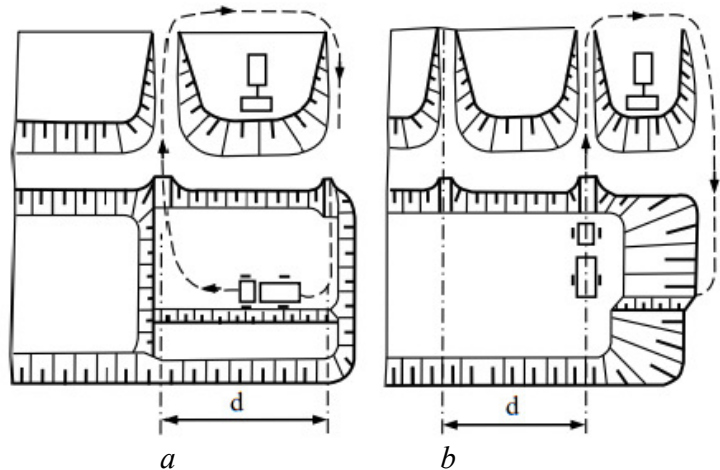

Fig. 6. Schemes of scraper-bulldozer technological complex [14]

Since the scraper is used as the main equipment, the area of its effective application in the extraction of sand-gravel mass is limited by the presence of boulders in the sediments.

Bulldozer-excavator technological complexes are effective for performing excavation works in quarries and placer deposits [14, 15], if:

1) the width of the work front up to 40-60 $\mathrm{m}$ and the thickness of the opening up to 4-6 m, the extraction and movement of rock is carried out by bulldozers, and dumping or loading of rock mass into vehicles-excavators (Fig. 7a,b);

2) the width of the work front is more than 40-60 m and overburden capacity is more than 4-6 m, the extraction and movement of rock is carried out by bulldozers, and dumping - excavators and bulldozers (Fig. 7c);

3 ) the excavator moves the pre-loosened rock mass into a temporary dump, and the bulldozer moves it to a permanent dump (Fig.7d). 


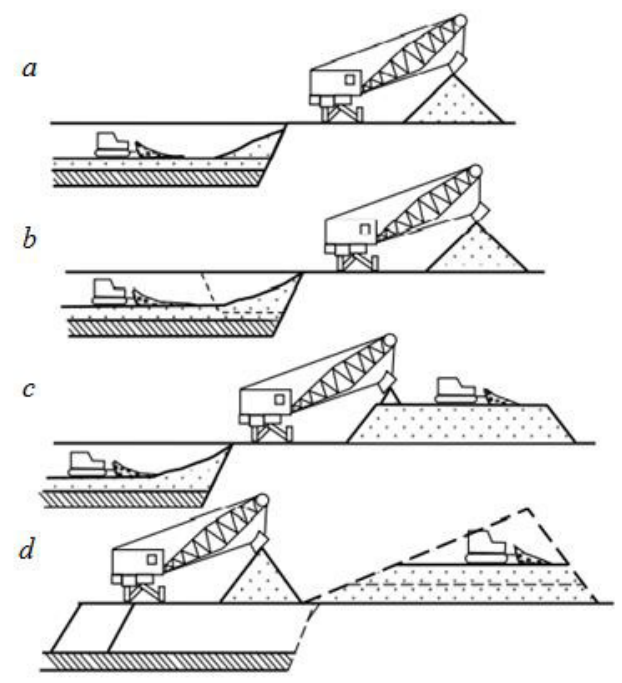

Fig. 7. Schemes of bulldozer-excavator technological complex

In this complex, bulldozers move the rock mass over short distances, and excavators remove mostly already loose rock. This creates the preconditions for achieving maximum performance of each unit of equipment.

When developing sand and gravel mass with a thickness of 6-10 $\mathrm{m}$ and the presence of boulders in it, the most appropriate will be the use of bulldozer-excavator-car (Fig. 8) or bulldozer-loader-car complex (Fig. 9) [14].

When bulldozers and excavators are used as extraction and loading equipment, the rock mass is moved by bulldozer to the stack after removal, from which it is loaded into vehicles by an excavator (Fig. 8 ). Bulldozer and loosening equipment is mounted on one tractor tractor, which allows you to alternately perform the processes of preparation and removal of one equipment, and intermediate stacking of rock mass ensures high technical and operational performance of the loading excavator. 

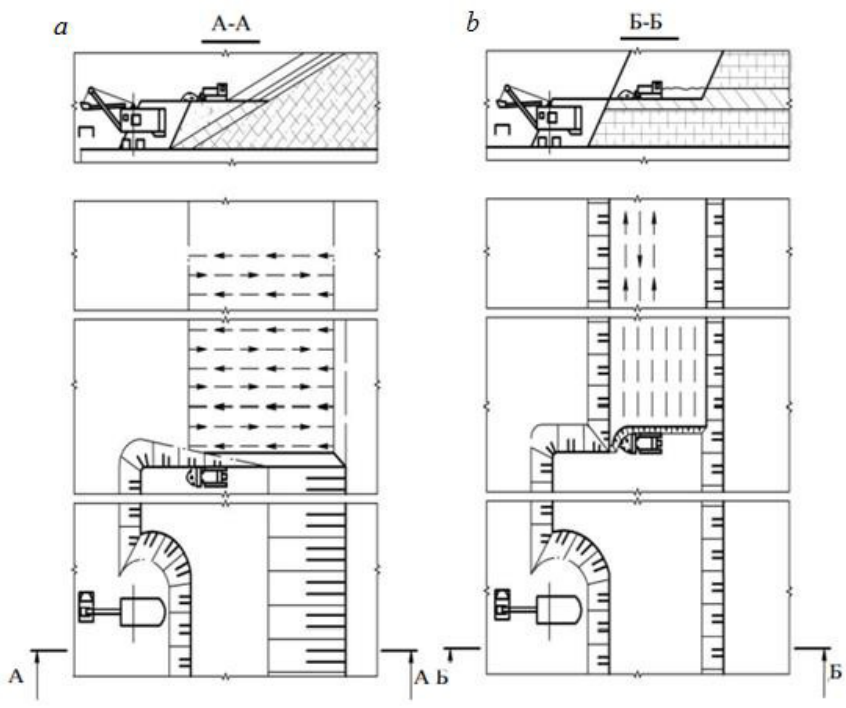

Fig. 8. Schemes of bulldozer-excavator-automobile technological complex: $a-$ loosening and extraction of inclined layers of rock; $b$ - loosening and removal of horizontal layers of rock [14]
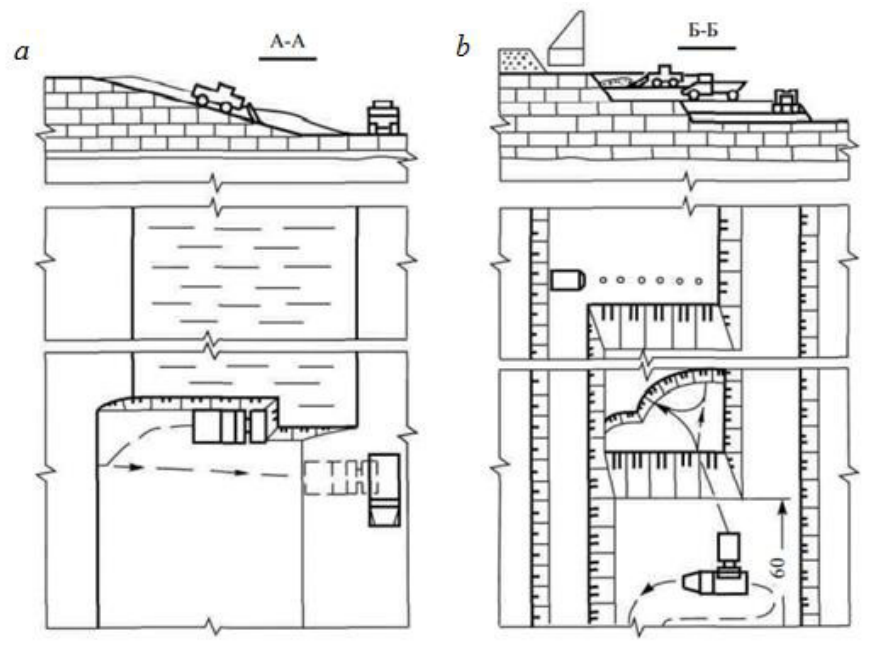

Fig. 9. Schemes of development of fluvioglacial deposits by inclined ( $a$ ) and horizontal $(b)$ layers with the use of loaders [14] 
When using loaders, the most effective scheme is the work of the front face (Fig. 9a) with the excavation and movement of the rock at an angle. Excavation end face in longitudinal holes, as well as site face and longitudinal face in transverse holes, which causes a rigid relationship of preparation, excavation and loading of rocks, is rational in some cases - with limited quarry length, storage of rocks in the produced space, to reduce the angle of the working board of the quarry.

High productivity of the excavator, absence of trench opening of ledges, reduction of width of working platforms and distances of transportation of rock mass are reached at bulldozer transfer of breeds on the lower ledges. The rock mass can be transferred from one or more ledges to the transport horizon of the lower ledge, where the excavator is shipped to vehicles. Such bulldozer handling is used in low-capacity quarries with limited surface area.

The height of the working ledge at the gross excavation is determined by the thickness of the layer of fluvioglacial deposits or the parameters of the excavator. At separate excavation by a face-site the possible height of a ledge with a normal frontal slope depends on its stability. When excavating the rock by a loader frontal face (inclined layers) or face-off platform with the slope of the ledge with subsequent loading of the rock into dump trucks, the rational height of the ledge depends on its angle of inclination and the thickness of the excavation layers and is 5-10 m. High productivity of the bulldozerripper and the excavator is reached at bulldozer extraction by inclined layers with stacking of breed, providing at the same time rational height of a ledge. It is usually 6-15 m, with the height of the stack varies from 3,5 to $5 \mathrm{~m}$, and its width - from 6 to $9 \mathrm{~m}$.

The productivity of bulldozers and loaders during the development of horizontal thin layers depends on the size of the ledge panel. Rational width of the ledge panel is $20-35 \mathrm{~m}$ and $30-60 \mathrm{~m}$ when loading sand-gravel mass, respectively, at the level of the sole and loosened layer of the ledge. The minimum length of the panel block (excavator block) during gross development is $70-100 \mathrm{~m}$.

Operational productivity of this complex of equipment can be limited by: productivity of a transport link; excavator performance; productivity of loaders - at their use as the extracting and transport equipment, and also at loading in dump trucks at big width of the 
panel and height of a ledge; productivity of bulldozers - at the big width of the panel and height of a ledge accordingly at excavation by a face-off platform and a frontal face.

Therefore, the choice of the type of technological complex of working equipment, its qualitative and quantitative complete set should be carried out taking into account the required amount of extraction of sand-gravel mass and the size of the working area [14].

Floating dredger are used only in the development of naturally or artificially watered sand and gravel rocks. Grab buckets and a ladle chain are most often used as an executive body [11]. Despite the low cost of extraction of sand-gravel mass by floating multi-bucket and grab shells, the technology of their extraction is generally not suitable for excavation work in the existing quarries of rocks. It requires, first of all, a clear organization of work on flooding of mining areas and prevention of water leakage from them, which is very difficult to achieve in the presence of lower ledges for the extraction of rocks.

\section{Geological situation within the studied deposits}

Within the studied Sosnivsky and Yaroshivsky deposits, the Dnieper climatolite is represented by water-glacial deposits of the lower stage - fP II $d n 1$ and the Upper Dnieper stage, represented by the marginal moraine $g P$ II $d n 3$ (Fig. 10, the arrow shows the direction of glacier movement).

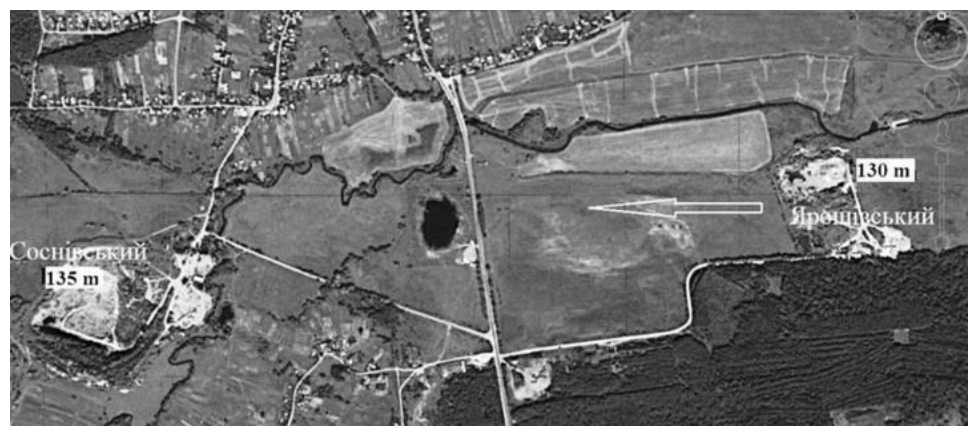

Fig. 10. Location of Sosnivsky and Yaroshivsky quarries [16]

Yaroshiv Granite Quarry is located on the right bank of the Irpin 
River in the village of Sosnivka, Northeast of the road Fastiv - Byshiv at a distance of $1 \mathrm{~km}$. Sosnivsky quarry is located 1,5 km southwest of Yaroshivsky.

Fluvioglacial deposits of the Sosnivskoye deposit are very dislocated, obliquely layered in the upper strata, various in granulometric composition, in the upper parts of the section there are remains of plants and trees.

Studies of water glacial and moraine deposits and boulders within the Sosnivsky deposit are reflected in scientific works [16].

Within the Sosnivskoye deposit, moraine and fluvioglacial deposits are spread over the entire area. The thickness of the sediments varies from $1 \mathrm{~m}$ to $25,6 \mathrm{~m}$. The section is represented by waterglacial sediments - $f P$ II $d n 1$ and marginal moraine $g P$ II $d n$.

Lithologically the rocks are represented as follows (bottom up):

- dense gray clay with a significant content (up to $45 \%$ ) of gravel and boulders of crystalline rocks with layers and lenses of sand, loam and sand (Fig. 11 and 12);

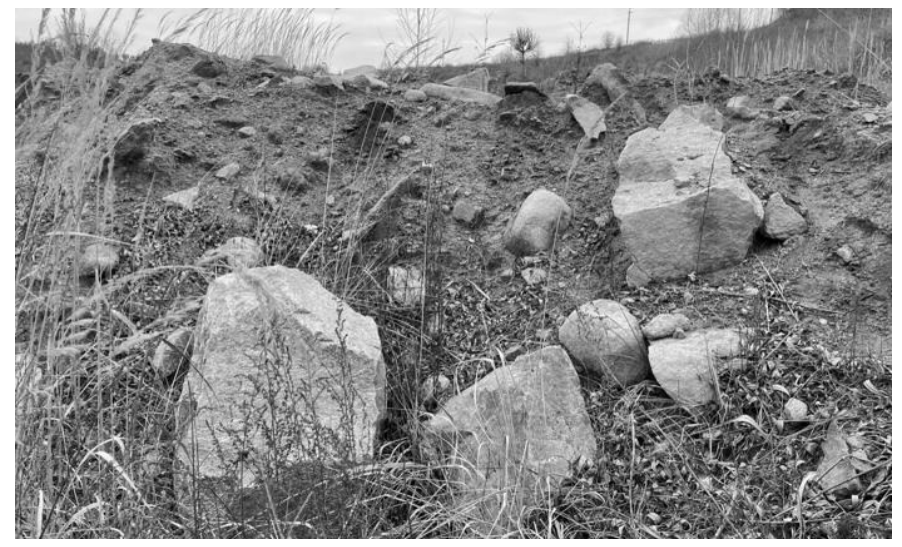

Fig. 11. Gravel-boulder material at the Sosnivsky deposit in the northern part of the overburden horizon

- next lies fine-grained sand, light gray to yellow-gray, with layers of clay. Closer to the day surface, the content of gravel-boulder material gradually decreases to $20-25 \%$. At the observation point in the northern part of the Sosnivsky quarry, oblique stratification of 
sand and sand with layers of loam is observed in fluvioglacial deposits (Fig. 13);

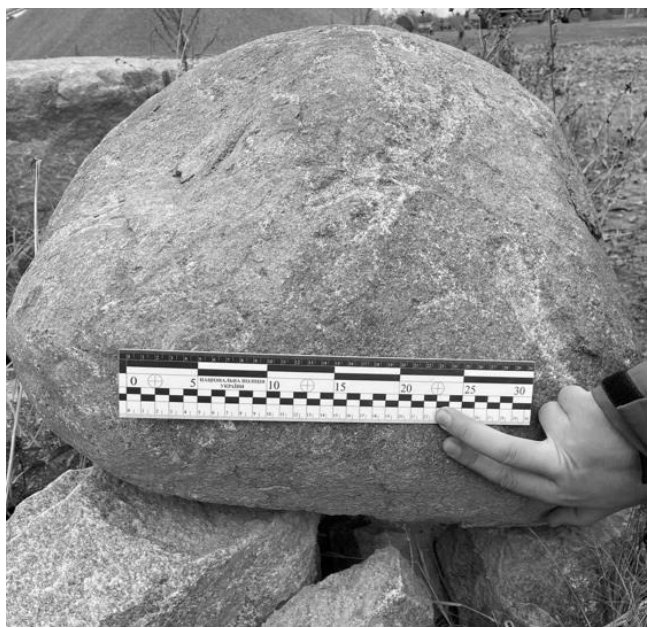

Fig. 12. Gravel-boulder material of the lower part of the section of fluvioglacial deposits

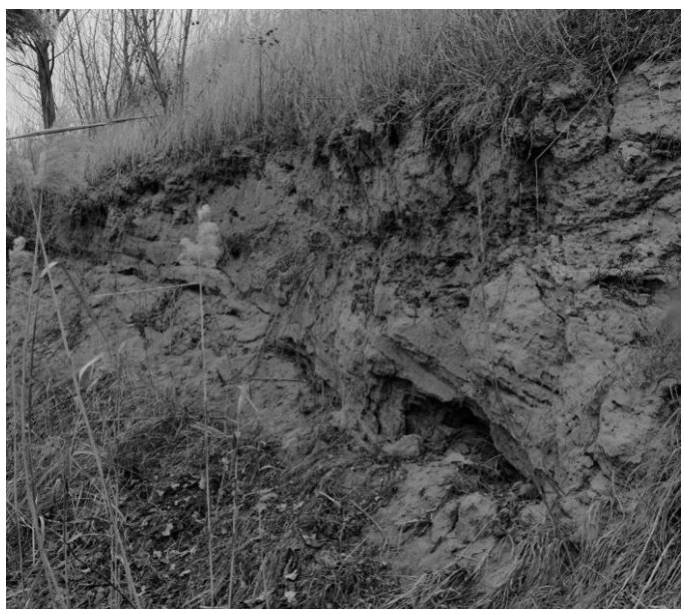

Fig. 13. Oblique stratification of sands, sandy loams and layers of loam

- cover the thickness of moraine and water-glacial deposits layers 
of loamy sandy gray, light gray with lenses of sand. The content of gravel of crystalline rocks from 5 to $10 \%$ is noted in the loam layers. Also in the upper part there is a layer of plant and wood remains (Fig. 14).

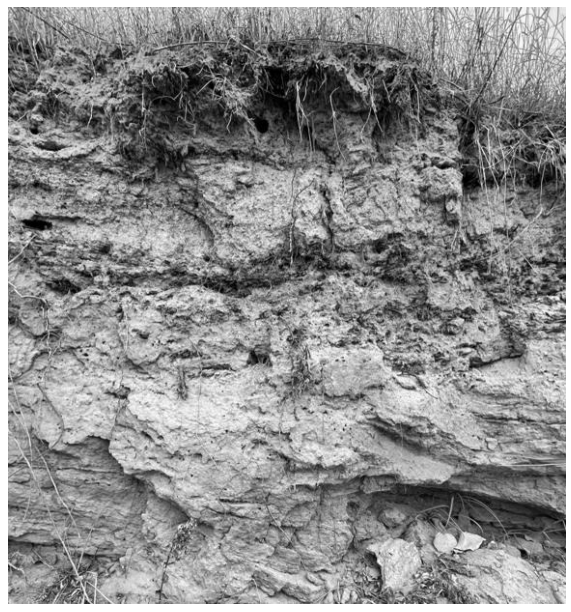

Fig. 14. The upper part of the thickness of fluvioglacial deposits

The image in fig. 12 gives a good idea of pellets of the crystalline rocks. The presence of holes on the surface indicates that the spherical shape is the result of contact with fragments of equal strength. The second factor that contributed to the pelletting was the movement inside the plastic-bulk mass, which limited the deviation from the general trajectory and did not allow, due to significant kinetic energy, to stop the picked up debris. The sizes of pellets fluctuate in the range from 1 centimeter to 3,0 $\mathrm{m}$. In general the oval form is considered inherent in contact zones at mutual movement of blocks [16]. The size of the katuns is determined by the scale of the phenomenon.

Thus, the fluvioglacial deposits of the Sosnivskoye deposit are very dislocated oblique-stratified in the upper strata, varying in granulometric composition, in the upper parts of the section there are remains of plants and wood. The deposit contains moraine and submoraine deposits of the Dnieper Glacier ( $v d \lg g P I I$ ) represented by loams, sands, sands with layers of clay, gravel, pebbles and granite boulders. Water-glacial deposits cover a large area of the Sosnivsky 
deposit and lie on the crust of granite weathering.

The geological situation within the Yaroshivsky deposit is as follows. In the south-eastern wall of the quarry (from bottom to top) are observed:

- lower proterozoic granites of the Fastiv complex visible thickness 10-15 m;

- black-gray thickness, the thickness of which in the depressions of the granite surface reaches $2 \mathrm{~m}$;

- Kyiv marl (thickness about $1 \mathrm{~m}$ );

- loess loam;

- alluvial sand.

Comparing the structure of Yaroshivsky and Sosnivsky granite quarries, we can note the following differences in the structure of the sedimentary stratum. The weathering crust is located above the granite surface in the Sosnovsky quarry. The most significant, up to 16 $\mathrm{m}$, is a layer of medium and fine-grained sand with layers of clay and inclusions of boulders and pebbles [16].

There is no weathering crust in the Yaroshiv quarry, and a blackand-glaucous layer lies over the granite massif. It opened when a quarry was developed on the north wall. There is a clear hollow in the wall, which is filled with black-glaucous sandstone loam with a significant content of gravel-boulder material (similar to the Sosnivsky deposit). This can also create a problem in the development of the deposit (Fig. 15).

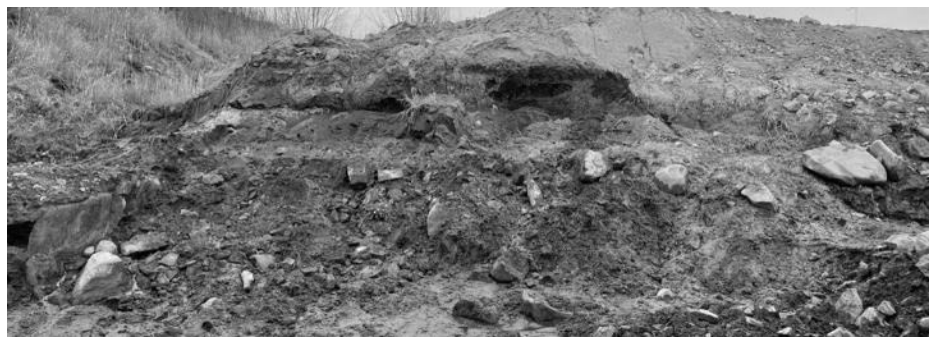

Fig. 15. Black-glaucous stratum of the rock mass in the Yaroshivsky quarry

Current state of mining operations at the open pit in the quarry of Sosnivsky deposit and proposed technological solutions

During the development of the Sosnivsky granite deposit, there 
was a problem of removing the layer of fluvioglacial deposits on the overburden ledge in the north-eastern part of the quarry. It turned out that the gravel-sand mixture has a significant amount of pebbles and boulders in some areas (from 40 to $80 \%$ ), and the existing equipment in the quarry is not able to remove this layer of sediment due to technical characteristics [10].

According to the classification of rocks for mechanical rotary drilling fluvioglacial deposits belong to category V. However, due to the sharp change in the concentration of gravel-boulder material of crystalline rocks, the drilling category may increase to $X$ (in some cases to $X I$ ).

The decision to prepare a layer of fluvioglacial deposits for extraction by drilling and blasting did not provide the desired result. When drilling wells, the drill rod is jammed in the massif due to the presence of a large amount of gravel-pebble-boulder material in the thickness of the layer (Fig. 16). Therefore, in these conditions it is necessary to develop special technological solutions based on a detailed study of the structure of occurrence of fluvioglacial deposits, existing technologies for the development of sand and gravel deposits and innovative approaches to solving this problem.

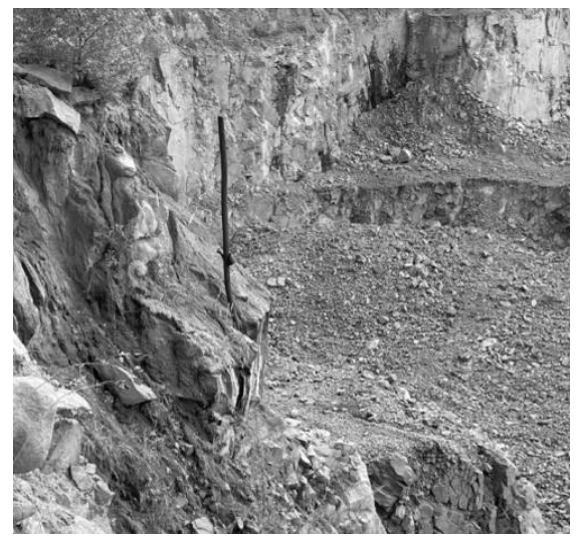

Fig. 16. Jammed drill rod in the layer of fluvioglacial deposits in the quarry of the Sosnivsky granite deposit [10]

As a result of assessing the current state of mining works and existing equipment in the quarries of Sosnivsky and Yaroshivsky de- 
posits, as well as analysis of possible technological complexes of equipment for removing the layer of fluvioglacial deposits, the authors concluded that the most efficient and technologically feasible will be combined bulldozer-excavator-automobile complex with the use of bulldozers-rippers (Fig. 17) [17].

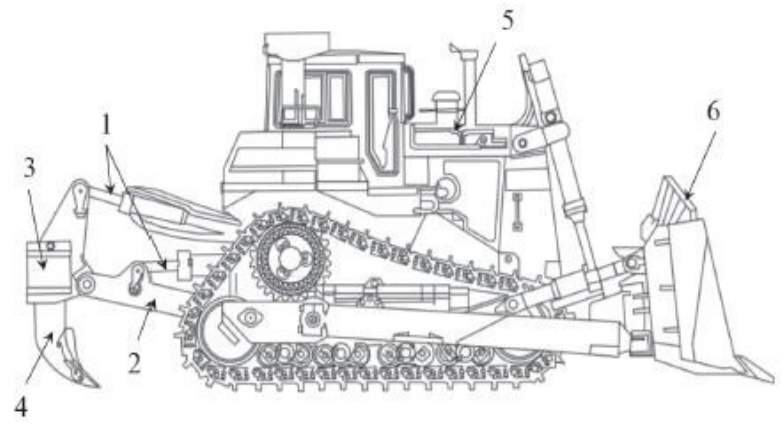

Fig. 17. Basic construction diagram of ripper: 1 -hydraulic system; 2 - frame;

3 -weather vane; 4 - ripper shank; 5 - bulldozer; 6 - dump [17]

At the same time, depending on the size of the working area, there are two options for bulldozer-excavator-automobile complex. The first option is to use a hydraulic backhoe excavator as a loading equipment, which should be placed on the roof of fluvioglacial deposits (Fig. 18) [18]. In the second option, it is proposed to use an excavator with a straight shovel, which loads the gravel-sand mass that dumps the bulldozer from the lower horizon of rocks (Fig. 19). These complexes are also the most acceptable in terms of the possibility of working in a limited working area and in the presence of a significant number of boulders in the sediments, which can be shifted and moved by powerful bulldozers-rippers.

The advent of powerful bulldozers and improvements in the design of modern rippers significantly expanded the scope of mechanical loosening, which allowed at this time its powerful use by some of the highly efficient production processes in opencast mining, in particular when removing a layer of fluvioglacial deposits/ 


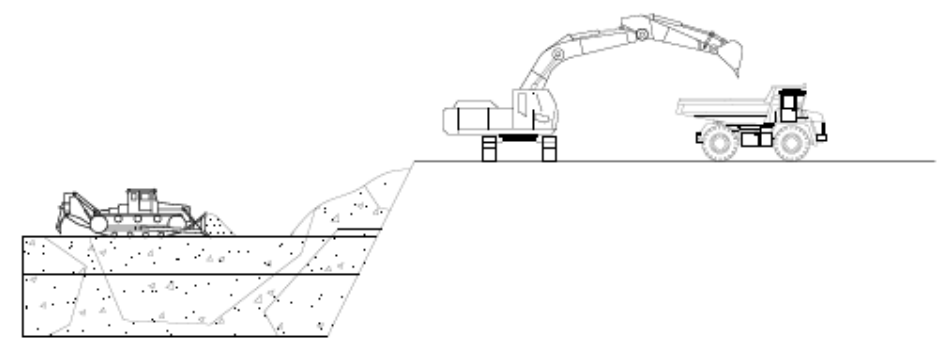

Fig. 18. Technological scheme of extraction of fluvioglacial deposits by a hydraulic excavator with a backhoe

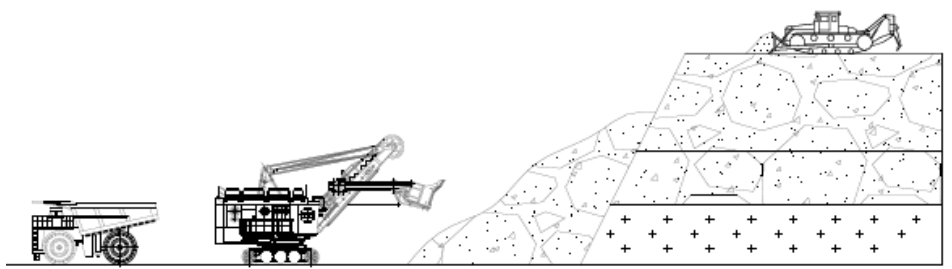

Fig. 19. Technological scheme of extraction of fluvioglacial deposits by an excavator of the "straight shovel" type from the lower placed horizon

As noted in [19], the variable productivity of excavators, namely the cycle time $t_{c}$, is significantly affected by both the average size of the fraction of rock mass and the percentage of oversized fractions. According to the results of research, scientists have established graphical and empirical dependences of the cycle duration of the excavator $t_{\mathrm{c}}, \mathrm{s}$, on the average size of a piece of rock mass

$$
t_{c}=a \cdot d_{m}^{b}
$$

where $d_{m}$ - the average size of a piece of rock mass, $\mathrm{m} ; a, b$-empirical coefficients that depend on the uniformity of the distribution of particle size distribution (variance).

If we assume that the rock mass is a sand-gravel mixture with unevenly distributed content of boulder material (logarithmic variance 1,3), then, according to [19], formula (3) will take the form 


$$
t_{c}=53,9 \cdot d_{m}^{0,2}
$$

In fig. 20 is a graph of the dependence of the change in the duration of the excavator cycle on the average size of the piece of fluvioglacial deposits $d_{\mathrm{m}}, \mathrm{mm}$. The analysis of the figure shows a gradual increase in the duration of the cycle with increasing average piece size in the fractional composition of gravel-sand mass, which is quite logical and natural. Within the studied interval of change of the size of a piece from 20 to $120 \mathrm{~mm}$ duration of a cycle changes 1,43 times from 24,6 to $35,3 \mathrm{~s}$.

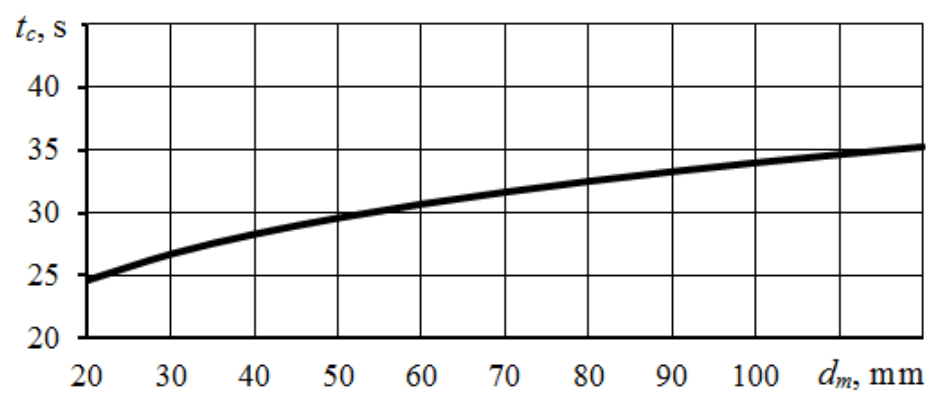

Fig. 20. The dependence of the change in the duration of the excavator cycle on the average size of the piece of fluvioglacial deposits

Variable performance of the excavator depends on the working equipment, physical-mechanical properties of rocks, parameters of the face and in general can be represented by the formula, $\mathrm{m}^{3} / \mathrm{sh}$

$$
Q_{s h}=\frac{3600 \cdot E}{t_{c}} \cdot T_{s h} \cdot k_{e} \cdot k_{i} \cdot k_{u},
$$

where $E$ is the capacity of the excavator bucket (Volvo EC460BLC bucket capacity is $\left.E=2,1 \mathrm{~m}^{3}\right) ; T_{\mathrm{sh}}$ - duration of work shift, $h$; $t_{c^{-}}$duration of the excavation cycle, $\mathrm{s} ; k_{u}$ - the coefficient of use of the excavator in time; $k_{u}=0,6 ; k_{i}$ - coefficient of influence of face parameters; $k_{e}$ - is the coefficient of excavation [2]

$$
k_{e}=\frac{k_{b f}}{k_{l}},
$$


where $k_{b f}$ - bucket filling (for backhoe $k_{b f}=1$; for a straight shovel $k_{b f}$ $=1,05$ ) [20]; $k_{l}$ - the coefficient of loosening of the rock mass in the bucket, $, k_{l}=1,2$

$$
k_{3}=k_{h} \cdot k_{a} \cdot k_{l r} \cdot k_{k},
$$

where $k_{h}$ - coefficient that takes into account the influence of the height of the face on the filling of the bucket of the excavator; $k_{h}=0,95 ; k_{a}$ - coefficient that takes into account the influence of the angle of rotation of the excavator on unloading (for the angle of rotation $180^{\circ} k_{a}=0,7$, for $\left.90^{\circ} k_{a}=1,0\right)$ [18]; $k_{l r}$ - coefficient that takes into account the conditions of loading the rock into the vehicle; $k_{k}$ - coefficient that takes into account the qualifications of the driver, $k_{k}=0,85$

The value of the coefficient, which takes into account the loading conditions of the rocks in the vehicles $k_{l r}$ is: for loading the rock mass with a backhoe excavator $k_{l r}=0,9$; for a straight-shovel excavator $k_{l r}=1,0$ [2].

For the conditions of the quarry Sosnivsky granite deposit using a hydraulic backhoe excavator, which is proposed to be placed on the roof of fluvioglacial deposits (see Fig. 17), formula (4) taking into account (5) and (6), as well as all recommended numerical indicators of coefficients, will take the form, $\mathrm{M}^{3} / \mathrm{sh}$

$$
Q_{s h}=\frac{15383,844}{t_{c}} .
$$

When using the second technological scheme of removal of fluvioglacial deposits, when the excavator with a straight shovel loads gravel-sand mass from the lower placed horizon of rocks (see Fig. 19), productivity, depending on the length of the cycle, will be determined, $\mathrm{M}^{3} / \mathrm{sh}$

$$
Q_{s h}=\frac{17947,818}{t_{c}} .
$$

In fig. 21 presents graphs of changes in the productivity of excavators depending on the size of the average piece of rock mass of fluvioglacial sediments for the two proposed technological schemes of excavation: when placing an excavator with a backhoe on the roof 
of fluvioglacial sediments (1); when placing the excavator type "straight shovel" on the lower level than working horizon (2).

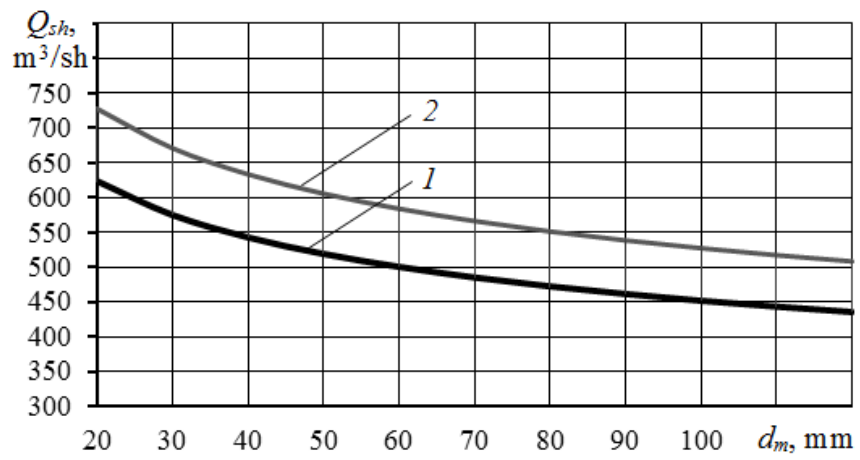

Fig. 21. Dependence of variable productivity of the excavator on the average size of a piece of gravel-sand mining mass: 1 - the backhoe excavator; 2 - excavator type «straight shovel»

As can be seen from Fig. 21, in general, the productivity of the excavator with a straight shovel is higher by $17 \%$ of the productivity of the backhoe. Within the studied change in the size of gravel-sand material from 20 to $120 \mathrm{~mm}$, the productivity of excavators also decreases 1,43 times: for the backhoe from $624,1 \mathrm{~m}^{3} / \mathrm{shift}$ to 436,2 $\mathrm{m}^{3} / \mathrm{shift}$; for straight shovel from $728,1 \mathrm{~m}^{3} / \mathrm{shift}$ to $508,8 \mathrm{~m}^{3} / \mathrm{shift}$.

According to the results of geological assessment of fluvioglacial deposits of overburden rocks at the Sosnivsky granite deposit, an approximate distribution of the fractional composition of gravel-sand mass was obtained (Table 4) according to the recommendations [11]. It is established that the average size of a piece of boulder-gravelsand mass is $101 \mathrm{~mm}$.

According to the graph presented in Fig. 21, the performance of the excavator will be:

- according to the first technological scheme of development (see Fig. 18) $450 \mathrm{~m}^{3} / \mathrm{shift}$;

- according to the second technological scheme of development (see Fig. 19) $530 \mathrm{~m}^{3} / \mathrm{shift}$.

Thus, it is established that the main reason for increasing the duration of the operating cycle and reducing the productivity of the ex- 
cavator is the increase in the size of the rock mass and the uneven distribution of the fractional composition characterized by dispersion.

Table 4

Fractional composition of overburden rocks of Sosnivsky deposit

\begin{tabular}{c|l|c|c}
\hline \multicolumn{2}{c|}{ Fractions } & Size, mm & Content, $\%$ \\
\hline \multirow{4}{*}{ Boulders } & large & $>400$ & 4,4 \\
\cline { 2 - 4 } & medium & $201-400$ & 7,53 \\
\cline { 2 - 4 } & small & $101-200$ & 8,57 \\
\hline \multirow{4}{*}{ Gravel } & large & $41-100$ & 7,4 \\
\cline { 2 - 4 } & medium & $21-40$ & 6,3 \\
\cline { 2 - 4 } & small & $5-20$ & 8,73 \\
\hline \multirow{5}{*}{ Sand } & coarse-grained & $1-5$ & 4,13 \\
\cline { 2 - 4 } & medium-grained & $0,5-1,0$ & 12,33 \\
\cline { 2 - 4 } & medium-fine-grained & $0,25-0,5$ & 14,8 \\
\cline { 2 - 4 } & fine-grained & $0,1-0,25$ & 17,57 \\
\hline \multicolumn{2}{l}{ Dusty and silt particles } & $0,005-0,1$ & 7,13 \\
\hline \multicolumn{2}{l}{ Clay particles } & $<0,005$ & 1,1 \\
\hline
\end{tabular}

\section{Conclusions}

According to the results of the research, the regularities of distribution, features and forms of distribution of fluvioglacial deposits on the territory of Ukraine have been established. The analysis of possible technological schemes of development of fluvioglacial deposits and equipment complexes is carried out, and the conditions of their effective application are established. Within the mining allotment of Sosnivsky and Yaroshivsky deposits, the main characteristics of occurrence of overburden rocks represented by fluvioglacial deposits were determined, and problems of mining in the quarry of Sosnivsky granite deposit were identified.

Based on the results of the assessment of the current state of mining operations and the availability of existing equipment in the quarries of Sosnivsky and Yaroshivsky deposits to remove the layer of fluvioglacial deposits, the use of a combined bulldozer-excavatorautomotive complex with the use of ripper bulldozers is proposed.

Depending on the size of the working area, there are two options for bulldozer-excavator-car complex. The first option involves the use of a hydraulic backhoe excavator, placed on the roof of fluvioglacial deposits. In the second option, it is proposed to use an excavator type «straight shovel», which is located on the lower placed 
horizon of rocks and loads the gravel-sand mass, which is dumped by a bulldozer.

There is obtained an empirical and graphical dependence of the variable productivity of the excavator on the average size of a piece of gravel-sand rock mass for the conditions of the quarry of the Sosnivsky granite deposit for the proposed technological schemes of working off overburden. It is established that within the studied changes in the size of gravel-sand material, namely from 20 to $120 \mathrm{~mm}$, the productivity of excavators is reduced by 1,43 times: for the backhoe excavator from $624,1 \mathrm{~m}^{3} / \mathrm{shift}$ to $436,2 \mathrm{~m}^{3} / \mathrm{shift}$; for straight shovel from $728,1 \mathrm{~m}^{3} /$ shift to $508,8 \mathrm{~m}^{3} / \mathrm{shift}$. In general, the productivity of the excavator with a straight shovel is $17 \%$ higher than the productivity of the backhoe.

Given the average size of a piece of boulder-gravel-sand mass, which is equal to $101 \mathrm{~mm}$, the productivity of the excavator will be:

- according to the first technological scheme of mining of $450 \mathrm{~m}^{3} / \mathrm{shift}$;

- according to the second technological scheme of mining $530 \mathrm{~m}^{3} / \mathrm{shift}$.

Since fluvioglacial deposits, as overburden rocks, in the contours of the field usually have a complex structure of occurrence and significant changes in the fluctuations of the deposit capacity, and the working area of the equipment may be limited, it is advisable to determine the productivity of the whole technological complex for extraction of gravel-sand mass. Therefore, the obtained performance of the excavator must be consistent with the capabilities and performance of the ripper bulldozer and road transport. This will be the direction of further research.

\section{References}

1. Berezovskij, N.I., Berezovskij, S.N., Dovnar, S.V., Onika, S.G. (2011). Razrabotka algoritmov dlja upravlenija proizvodstvennymi tehnologijami: monografija. Minsk: BIP-S Pljus.

2. Bujanov, Ju.D., Krasnopol'skij, A.A. (1980). Razrabotka mestorozhdenij nerudnyh poleznyh iskopaemyh. Moskva: Nedra.

3. Rzhevskij, V.V. (1975). Tehnologija i kompleksnaja mehanizacija otkrytyh gornyh rabot. Moskva: Nedra.

4. Arsent'ev, A.I. (2002). Opredelenie proizvoditel'nosti i granic ka-r'erov. Sankt-Peterburg: S.-PGI. 
5. Onika, S.G. (2006). Proektirovanie kar'erov. Minsk: BNTU.

6. Komarovskij, M. E. (2011). Uchebnaja obshhegeologicheskaja praktika na Minskom poligone: uchebnoe metodicheskoe posobie. Minsk: BGU.

7. Vovk, V.M. (2022). Geologichnyj slovnyk https://geodictionary.com.ua/node/4428

8. Manjuk, V. V. (2017). Pro zminennja polozhennja pivdennoi' granyci Dniprovs'kogo (rys'kogo) zledeninnja. Visnyk Dnipropetrovs'kogo universytetu. Serija : Geologija. Geografija, 21, 99-110.

9. Ohar (2021) Carboniferous fauna from erratics in the Hradyzk area (Poltava region, Ukraine): paleo-ice streams indicator of the Dnipro glacial maximum, Historical Biology, 33:1, 78-87.

10. Lytvynchuk, I.D., Frolov, O.O. (2021). Problemy vyjmannja fljuviogljacial'nyh vidkladiv na rozkryvnyh ustupah rodovyshh skel'nyh budivel'nyh porid. Tezy VIII Vseukrai'ns'koi' naukovo-praktychnoi' konferencii' studentiv, aspirantiv ta molodyh vchenyh «Perspektyvy rozvytku girnychoi' spravy ta racional'nogo vykorystannja pryrodnyh resursiv». Zhytomyr: Zhytomyrs'ka politehnika, 65-69.

11. Malysheva, N.A., Sirenko, V.N. (1977). Tehnologija razrabotki mestorozhdenij nerudnyh stroitel'nyh materialov. Moskva: Nedra.

12. Jarcev, V. I., Gubin, V. N., Vysockij, Je. A., Il'kevich, G. I., Gurinovich, A. I. (2001). Poiski i razvedka mestorozhdenij mineral'nogo stroitel'nogo syr'ja: Ucheb. posobie. Minsk: BGU.

13. Bujanov, Ju.D. (1988). Razrabotka gravijno-peschanyh mestorozhdenij. Moskva: Nedra.

14. Rakishev, B.R. (2015). Tehnologicheskie kompleksy otkrytyh gornyh rabot: Uchebnik. Almaty.

15. Drizhenko, A.Ju. (2011). Kar'ernye tehnologicheskie gornotransportnye sistemy: monografija. Dnepr: NGU.

16. Pazynych, V.G. (2019). Rekonstrukcija postgljacial'nyh podij v basejni Dnipra: monografija. https://www.academia.edu/11219641/Reconstruction_of_ postglacial_events_in_Dnipro_river_basin

17. Argimbaev, K. R., Ligockij, D. N., Loginov, E. V. (2020). Bul'dozernaja tehnologija otkrytoj razrabotki izvestnjakovo-dolomitovyh mestorozhdenij: Gornyj informacionno-analiticheskij bjulleten', 3, 16-29.

18. Frolov, O., Beltek M. (2021). Influence of the hydraulic excavator location with a backhoe in the face on the efficiency of rock mass excavation. Вісник КрНУ імені Михайла Остроградського. Кременчук: КрНУ, 3/2021 (128), 70-75.

19. Ugol'nikov, V.K., Gavrishev, S.E., Ugol'nikov, N.V. (2007). Vlijanie granulometricheskogo sostava gornoj massy na proizvoditel'nost' jekskavatorov. Gornyj informacionno-analiticheskij bjulleten', 2(6), 73-81.

20. Normy tehnologicheskogo proektirovanija predprijatij promyshlennosti nerudnyh stroitel'nyh materialov (1977). Leningrad: Strojizdat. 